\title{
GEOSTATISTICAL ANALYSIS OF A GEOCHEMICAL DATASET (1)
}

\author{
JORGE PAZ-FERREIRO $\left(\left(^{*}\right)\right.$; EVA VIDAL VÁZQUEZ $\left({ }^{2}\right)$; SIDNEY ROSA VIEIRA $\left({ }^{3}\right)$
}

\begin{abstract}
The application of geostatistics to data obtained from geochemical prospecting process can provide useful information for evaluating mineralization potential. The objective of this study was to evaluate the spatial distribution of $\mathrm{Au}, \mathrm{As}$ and $\mathrm{Sb}$ contents over a large area of the Coruña province, Spain. A geochemical survey was carried out from which a data set with 323 samples was collected. Macroelements and trace elements were determined by routine analytical techniques. The spatial variability was assessed using semivariogram and crosssemivariogram as well as indicator semivariogram analysis. Frequency distributions of the studied elements departed from normal, as indicated by skewness and kurtosis coefficients. Coefficients of variation ranked as follows: $\mathrm{Sb}<\mathrm{As}<\mathrm{Au}$. Significant correlation coefficients between $\mathrm{Au}, \mathrm{Sb}$ and $\mathrm{As}$ were found, even though the correlation values were low. Spherical models with nugget effects ranging from 50\% (As) to 57.8\% (Au) were fitted to the experimental semivariograms. Cross semivariograms of Au versus $\mathrm{Sb}$ and As showed smaller nugget variance than individual semivariograms. Indicator semivariograms were calculated taken mean, median, and different percentiles as threshold values. Ordinary kriging, cokriging, and indicator kriging were performed to generate geochemical maps. The method has succeeded in effectively extracting useful information, and improving the analysis of the metallogenic and ore-controlling factors, thereby playing an important role in qualitative and quantitative predictions.
\end{abstract}

Key words: geochemical survey, geostatistics, kriging, indicator kriging, cokriging.

\section{RESUMO}

\section{ANÁLISES GEOESTATÍSTICAS DE UMA SÉRIE DE DADOS GEOQUÍMICOS}

A aplicação da geoestatística para o tratamento de dados de prospeç̧ão pode proporcionar informações úteis para a avaliação do potencial de mineralização. O objetivo deste estudo foi avaliar a distribuição espacial dos conteúdos de $\mathrm{Au}$, As e $\mathrm{Sb}$ sobre uma grande área da província de Coruña, Espanha. Foi efetuada uma prospeção geoquímica obtendo-se um conjunto de 323 amostras. Determinou-se o conteúdo de macroelementos e elementos traço, por técnicas de análises de rotina. A variabilidade espacial foi avaliada mediante semivariogramas ordinários, semivariogramas cruzados e semivariogramas indicadores. Os coeficientes de assimetria e curtose, permitiram comprovar que as distribuições de frequência estudadas não se ajustam a uma distribuição normal. Os coeficientes de variação aumentam na ordem: $\mathrm{Sb}<\mathrm{As}<\mathrm{Au}$. Foram observados coeficientes de correlação significativos entre $\mathrm{Au}, \mathrm{Sb}$ e As, aínda que baixos. Foram ajustados modelos esféricos aos semivariogramas cujos valores de efeito pepita variaram entre 50\% (As) e 57,8\% (Au). Os semivariogramas cruzados de $\mathrm{Au}$ versus $\mathrm{Sb}$ e As proporcionaram menores efeitos pepita do que os semivariogramas individuais. Calcularam-se semivariogramas indicadores tomando média, mediana e distintos percentis, como referência. Foram obtidos mapas geoquímicos usando krigagem, krigagem indicatriz e cokrigagem para delimitar as anomalias geoquímicas. Os métodos empregados permitiram extrair informações de forma eficiente e melhorar análise dos fatores que controlam a mineralização e contribuindo assim para predições qualitativas e quantitativas.

Palavras-chave: prospeçao geoquímica, geoestatística, krigagem, krigagem indicatriz, cokrigagem.

(1) Received for publication in September 15, 2008 and accepted in May 10, 2010.

() Facultad de Ciencias. Universidade da Coruña. Campus A Zapateira. C.P. 15071, A Coruña, Spain. E-mail: jpaz@udc.es (*) Corresponding author. evidal@udc.es

(3) Instituto Agronômico. Avenida Barão de Itapura, 1481, Guanabara 13020-902 Campinas (SP), Brasil. E-mail: sidney@iac.sp.gov.br 


\section{INTRODUCTION}

A geochemical study in mining exploration consists of two particular stages. The first involves collecting and analyzing various types of geological materials, such as soils, stream sediments and rocks. The second step, concerns the treatment and interpretation of available numerical information by plotting the geochemical values on maps, and interpretation of the results. After discovery of the mineral deposit, geochemical sampling plays a key role in the delineation of the mineralization process. Sometimes mineralization can be extremely subtle, if not impossible to recognize in hand specimen. Without the use of geochemical sampling methods, many known ore deposits would probably not have been discovered. Historically these methods have been some of the most productive among any other methods used in mineral exploration.

The collected materials may be analyzed for any number of elements. Which elements are chosen for analysis depends on budget, the geology of the area, and the commodity which is being sought. Often there are specific elements or suites of elements which are known to be associated with specific types of mineralization. Therefore it is possible to evaluate the potential for the existence of certain types of mineralization by evaluating which elements are associated in a given area. The specific features of geochemical exploration studies are the treatment of a huge amount of data, the imprecision of this data, the multivariate character, and especially, the spatial dependence of variables. This latter characteristic gives these variables their regionalized behavior (JOuRNEL and HuIJBREGTS, 1978), as the basis of geostatistical methods.

Geostatistical interpolation (kriging) provides the best linear unbiased prediction for spatially dependent properties (Journel and HuijBregts, 1978; VIEIRA et al., 1997). Kriging has been frequently used for the spatial interpolation of mineral deposits (SousA, 1989; JimÉnez Espinosa and Chica Olmo, 1999; Reis et al., 2003; 2004). However, the great variability on ore concentration in conjunction with sparse sampling may mask the spatial dependence (JourNeL, 1983). An important problem associated with the analysis of the geochemical information is the presence of skewed distributions with high coefficient of variation. Another problem is that values below detection limit are grouped at detection limit. Experimental semivariograms become extremely sensitive to high and low values, and may be practically useless in some cases. In these situations, two traditional solutions are proposed: (i) trim off the extreme values, based on geological or probabilistic criteria; or, (ii) transform the data by means of a smoothing function or the natural logarithms. The first approach is very simplistic and not acceptable when these data carry the most valuable structural information, not to mention their economic weight. Log-transformations are non-linear, and that calls for non-linear estimation techniques (i.e., disjunctive kriging), which require a hypothesis about the distribution. The lognormal kriging estimator provides an approximately unbiased estimator, but error estimations are often exaggerated and it only works well when the transformed data are a Gaussian random function. Although logarithmic transformation is one approach which has been frequently used for highly skewed data (CAMBARDELla et al., 1994; VAN MeirvenNe et al., 1996), real data sets, unfortunately may not meet the severe requirements for using this technique.

The indicator transformation is also an alternative for dealing with the data, which have a positively skewed distribution with a few extreme values. This method can transform any data set having an asymmetric distribution into the normal scores, which have a standard normal distribution. Then, the kriging estimation can be performed in the normal-scored space (Goovaerts, 1997; Chilès and Delfiner, 1999).

Multi element surveys are routinely performed owing to the fact that geochemical variables are frequently associated with each other. Significant correlations between variables allow joint estimation of values by corregionalization. Therefore, if large nugget effect happens for individual semivariograms, cokriging may be a method of analysis particularly useful (CHILÈs and DeLFINER, 1999; VIEIRA, 2000).

The west of La Coruña province, Galicia (NW Spain) is an area of mining interest because of the presence of $\mathrm{Au}$ mineralization (PORTER and Álvarez MoRÁn, 1992). After geochemical exploration surveys, $\mathrm{Au}$ data presents significant problems for numerical treatment. Arsenic has been used to evaluate the metallogenetic importance of this zone. In other words, As can be considered a pathfinder of $\mathrm{Au}$ in this zone, as the two are genetically related (JIMÉNEZ Espinosa and Chica Olmo, 1999). The objective of this study was to evaluate the spatial distribution of $\mathrm{Au}$, $\mathrm{As}$ and $\mathrm{Sb}$ contents over a large area of the Coruña province, Spain.

\section{MATERIAL AND METHODS}

\section{Sampling and analysis}

The study area is located in La Coruña province, Galicia, NW of Spain, a zone of mining interest due to concentrations of $\mathrm{Au}$. The discovered mineralization is characterized by slightly different geological settings and mineralogical assemblages. In this area $\mathrm{Au}$ is associated 
to arsenopyrite (Porter and Álvarez Morán, 1992). A large number of elements (e.g. As, $\mathrm{Sb}, \mathrm{Bi}, \mathrm{Pb} . \mathrm{Cu}, \mathrm{Ag}$, $\mathrm{Cd}$, Se and $\mathrm{Te}$ ) are enriched in Au bearing deposits.

Geologically this area is located in the Iberian Massif and more specifically in the Galicia Tras os Montes Zone. Concerning the local geology, the study area comprises predominantly acid rocks, mainly alkaline and calcalkaline granites, gneiss and migmatites. The most significant structural feature of this zone is the presence of a mylonitic band, with an approximate NESW orientation.

The data set comprises 323 samples taken below the A horizon at the $30-40 \mathrm{~cm}$ depth, as it is traditionally done in geochemical surveys within the temperate climatic zone. Therefore, samples were collected preferentially in the B horizon. Occasionally, in places where the $\mathrm{B}$ horizon was not present, samples were collected in the BC or C horizon. Samples were taken in a rectilinear grid at equal distances of $40 \mathrm{~m}$ and along evenly spaced lines of $70 \mathrm{~m}$ (Figure 1). The lines were perpendicular to the NE-SW trending tectonic structures.

Samples were air dried and sieved. Eighteen chemical elements were analyzed for each sample, generating a data matrix of 323 rows and 18 columns.

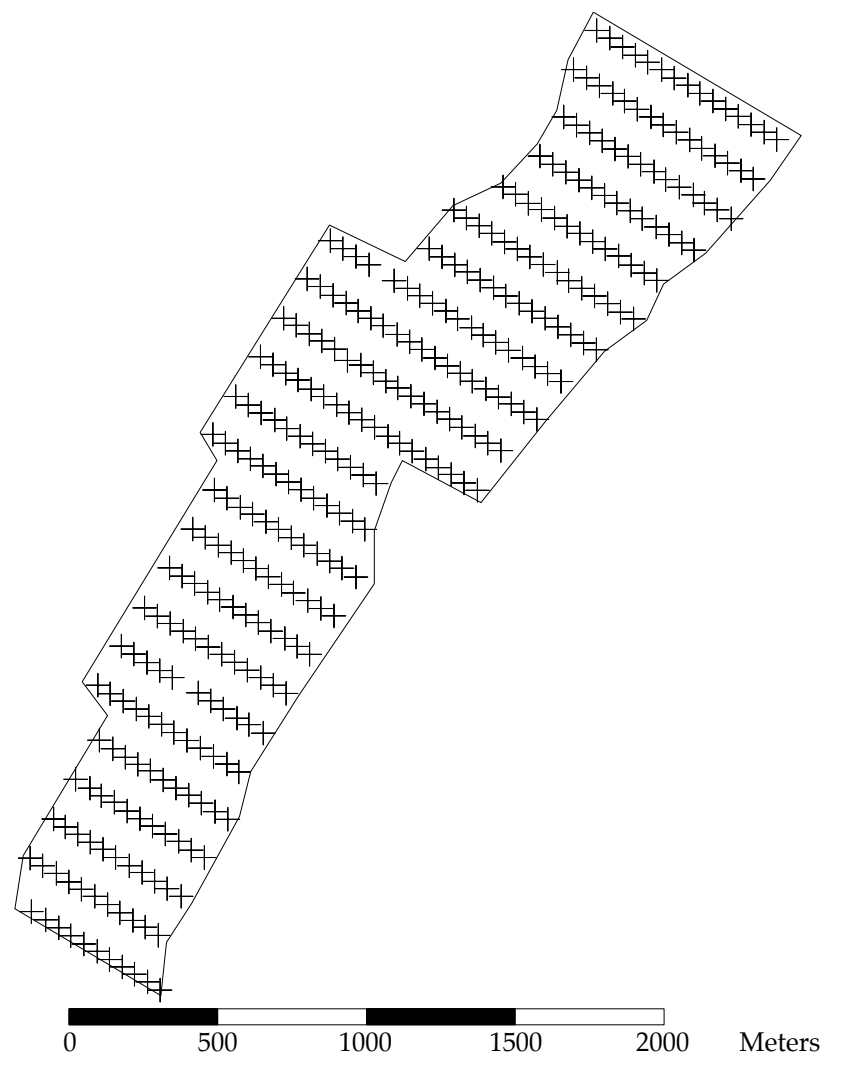

Figure 1. Sampling scheme for the study data set with 323 points.
The sample digestion method depended on the element being targeted. Aqua regia was used for $\mathrm{Au}$ and $\mathrm{Ag}$, while a hydrofluoric-perchloric $\left(\mathrm{HF}-\mathrm{HClO}_{4}\right)$ acid attack was performed for $\mathrm{As}, \mathrm{Sb}$ and Se. For the remaining elements a hydrofluoric-perchloric-nitric ( $\mathrm{HF}-\mathrm{HClO}_{4}-$ $\mathrm{NO}_{3} \mathrm{H}$ ) digestion was used (LeCOMTE and SonDaG, 1980; ReIs et al., 2004). For this study Au was analyzed and also As and $\mathrm{Sb}$ were retained because these two elements are considered the most useful indicators of the presence of gold, usually referred to as pathfinder elements. Gold was analyzed by Inductively-coupled PlasmaAtomic Emission Spectroscopy (ICP-AS). The analytical equipment was atomic absorption spectrometry-hybride generation for As and $\mathrm{Sb}$. The detection limit was $5 \mathrm{ppm}$ for $\mathrm{As}$ and $\mathrm{Sb}$ and $2 \mathrm{ppm}$ for $\mathrm{Au}$.

\section{Statistical and Geostatistical analysis}

The preliminary analysis was performed by calculation of the main statistical moments (mean, minimum value, maximum value, standard deviation, coefficient of variation, skewness and kurtosis). The linear correlation coefficient between $\mathrm{Au}$, $\mathrm{As}$ and $\mathrm{Sb}$ also was calculated.

The spatial variability was assessed using semivariogram and cross-semivariogram analysis and maps obtained with kriging and cokriging estimation (VIEIRA, 2000). Semivariograms were calculated using the equation,

$\gamma^{*}(h)=\frac{1}{2 N(h)} \sum_{i=1}^{N(h)}\left[Z\left(x_{i}\right)-Z\left(x_{i}+h\right)\right]^{2}$

where $\gamma^{*}(h)$ is experimental semivariance, $\mathrm{N}(\mathrm{h})$ is the number pairs of values $\mathrm{Z}\left(\mathrm{x}_{\mathrm{i}}\right), \mathrm{Z}\left(\mathrm{x}_{\mathrm{i}}+\mathrm{h}\right)$ separated by a distance $h$.

Experimental semivariograms were fitted by theoretical models. The initial selection was made on the basis of visual observation followed by an automatic (least-squares) estimation of semivariogram parameters, until the fitted model becomes theoretically consistent. Cross-validation was used to assess the precision of the interpolation method (VIEIRA, 2000).

Cross-semivariograms were analysed for the pairs of variables which showed significant correlation. Calculations were performed by means of the equation,

$\gamma_{l m}(h)=\frac{1}{2 N(h)} \sum_{i=1}^{N(h)}\left[Z_{l}\left(x_{1}\right)-Z_{l}\left(x_{i}+h\right)\right]\left[Z_{m}\left(x_{l}\right)-Z_{m}\left(x_{i}+h\right)\right]$

where $\gamma_{\mathrm{lm}}(h)$ is experimental cross semivariance, $\mathrm{N}(\mathrm{h})$ is the number pairs of measured values for the variable $Z_{l^{\prime}} Z_{1}\left(x_{1}\right), Z_{1}\left(x_{i}+h\right)$, and $Z_{m^{\prime}} Z_{m}\left(x_{1}\right), Z_{m}\left(x_{i}+h\right)$ separated by a distance $h$, in both cases. 
The indicator kriging is a nonparametric distribution free estimation method. It is based on the transformation of raw data as a function of an indicator. It results on a new data set consisting of only "zeros" and "ones", namely indicator variables, after the establishment of a series of cut-offs, $z_{\mathrm{k}^{\prime}}$ of the continuous function $z\left(x_{\mathrm{i}}\right)$. Therefore, the indicator function is defined as a step function of $z$ :

$i\left(\bar{x}_{i} ; z_{k}\right)=\left\{\begin{array}{l}1, \text { if } z\left(\bar{x}_{i}\right) \leq z_{k} \\ 0, \text { otherwise }\end{array}\right.$

The kriging and the cokriging techniques were used to estimate the values for unsampled points with minimum variance and the indicator kriging allows estimating probabilities of occurrence of the studied element above a threshold (VIEIRA, 2000). Maps of spatial variability were constructed using the software SURFER 7.0 (GOLDEN SOFTWARE, 1999).

\section{RESULTS AND DISCUSSION}

Table 1 shows a statistical summary for $\mathrm{Au}$, As and $\mathrm{Sb}$. Frequency distributions of these three elements considering the percentage of samples per class is presented in Figure 2.

Concentrations of $\mathrm{Au}, \mathrm{As}$ and $\mathrm{Sb}$, showed an important amount of variability and all three were strongly positive skewed, as a few extreme values appear in the data set. Moreover, most of the Au and Sb samples showed very low values that lie close to the detection limit. Coefficients of variation were 182.8, 101.7 and 49.2 for $\mathrm{Au}, \mathrm{As}$ and $\mathrm{Sb}$, respectively. This results in difficulties in the application of current geostatistical techniques.

Gold concentration range was between the detection limit, $2 \mathrm{ppm}$, and a maximum of $360 \mathrm{ppm}$. Similarly, Sb ranged from 5 to $35 \mathrm{ppm}$. Arsenic exhibits higher mean values than $\mathrm{Au}$ and $\mathrm{Sb}$, with a range of concentrations between 12 and $4076 \mathrm{ppm}$. Arsenic can be considered as a pathfinder of $\mathrm{Au}$, therefore it can be considered appropriate at a first sight as a secondary variable in the geostatistical analysis of $\mathrm{Au}$. However in our study case the correlation coefficients between $\mathrm{Au}$ and $\mathrm{As}$ was low $\left(\mathrm{R}^{2}=0.10\right)$, even though it is was significant $(\mathrm{P}<0.05)$ allowing corregionalization. Jiménez Espinosa and Chica Olmo (1999) found a higher correlation coefficient $\left(\mathrm{R}^{2}=0.76\right)$ between $\mathrm{Au}$ and $\mathrm{As}$ in a neighboring deposit of the study mining district.
Correlation coefficient between $\mathrm{Au}$ and $\mathrm{Sb}$ was a little higher $\left(R^{2}=0.14\right)$, but the linear dependence between these elements also was weak. Both $\mathrm{As}$ and $\mathrm{Sb}$ were used as auxiliary variables for geoestatistical analysis.

The patterns of spatial variability for $\mathrm{Au}$, As and $\mathrm{Sb}$ were assessed by semivariogram, indicator semivariograms and cross-semivariogram analysis. Figure 3 shows the experimental semivariograms together with models fitted to them and Table 2 lists parameters of these models. Semivariograms could be fitted quite well over the spatial scale of interest by spherical models with a nugget and a spatial component. The nugget effect was rather high with values of the dependence ratio, $\mathrm{C}_{0} /\left(\mathrm{C}_{0}+\mathrm{C}_{1}\right)$, of $55.97 \%$ for $\mathrm{Au}, 50$ $\%$ for As and $55.44 \%$ for $\mathrm{Sb}$, which indicate moderate spatial dependence (CAMBARDELLA et al., 1994). Therefore at small distances the three studied elements exhibits a rather low degree of continuity and the patterns of spatial variability at this scale is not very different. The range of spatial dependence was between $271.9 \mathrm{~m}(\mathrm{Au})$ and $515.4 \mathrm{~m}(\mathrm{Sb})$.

The individual semivariograms for $\mathrm{Au}, \mathrm{As}$ and $\mathrm{Sb}$ could be fitted quite well. For example, regression coefficients $\left(\mathrm{R}^{2}\right)$ between experimental and modelled data points were 0.996, 0.994 and 0.996 for $\mathrm{Au}$, As and $\mathrm{Sb}$, respectively. The goodness of fit was evidenced by the commonly used parameters of cross-validation, such as mean error and root mean square error (data not shown).

Scatter plots of the three studied elements show that locally extreme values are surrounded by much smaller ones. In this situation, there will be huge spatial variation among observations over a short distance, and the fitted semivariogram model usually has a large nugget effect. The large nugget effect means the variable is not very regular and is discontinuous from point to point. The higher is the nugget effect, the lower the spatial dependence. Kriging estimations using semivariograms with large nugget effect exhibit high kriging estimation errors and as the nugget effect increases and approaches pure nugget effect any map generated by using the kriging process will not be very meaningful.

Indicator semivariograms were calculated taking the mean, the median and different percentiles as threshold values. The most reliable results were

Table 1. Summary statistics of the variables studied

\begin{tabular}{lccccccc}
\hline Element & Mean & Variance & C.V. & Minimum & Maximum & Skewness & Kurtosis \\
\hline $\mathrm{Au}$ & 24.81 & 2057 & 182.8 & 2 & 360 & 4.371 & 23.15 \\
$\mathrm{As}$ & 609.1 & 383500 & 101.7 & 12 & 4076 & 1.916 & 4.927 \\
$\mathrm{Sb}$ & 6.796 & 11.18 & 49.21 & 5 & 35 & 3.277 & 17.76 \\
\hline
\end{tabular}



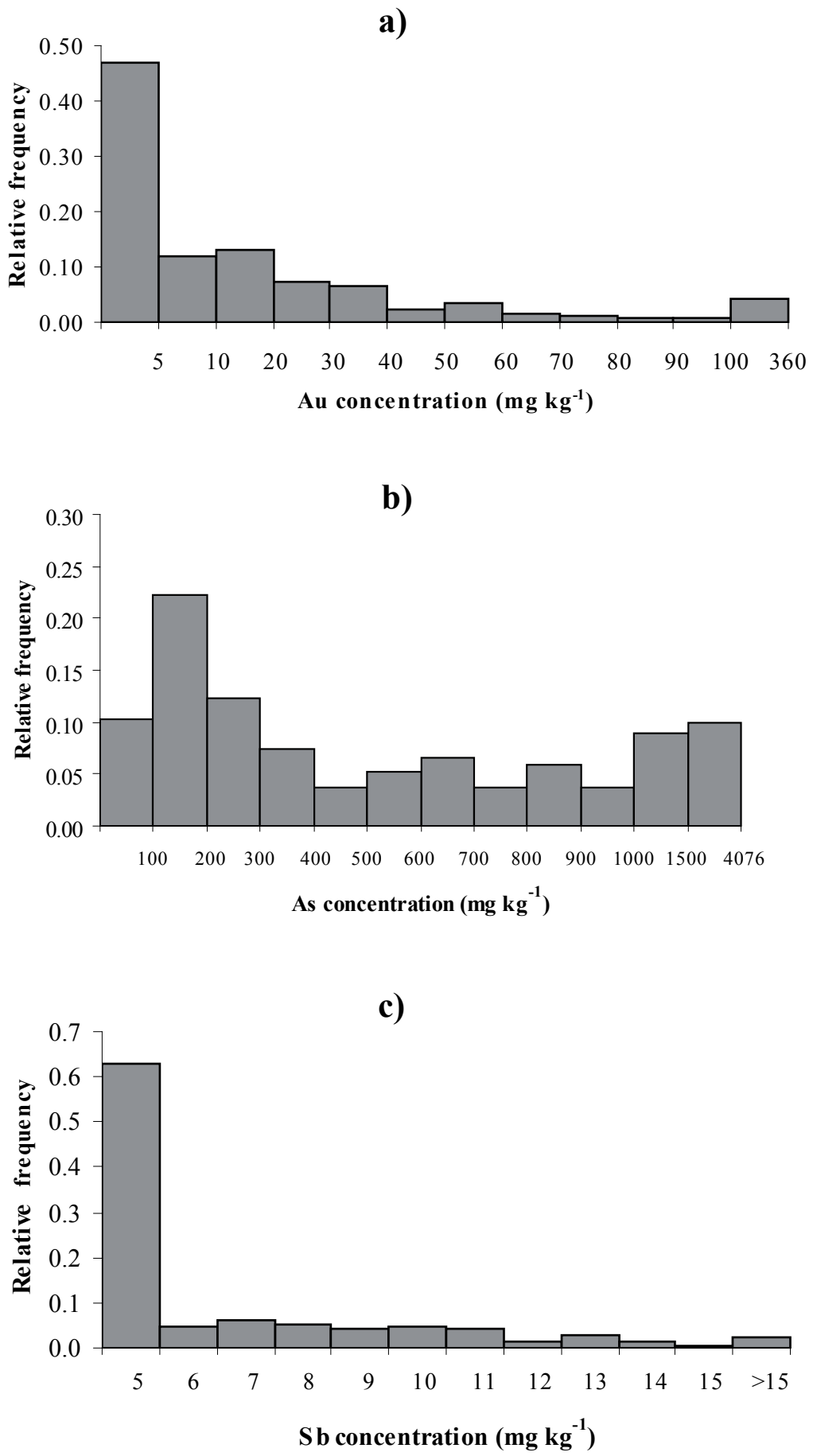

Figure 2. Frequency distributions for $\mathrm{Au}(\mathrm{a})$, As (b) and $\mathrm{Sb}$ (c).

Table 2. Fitted semivariogram models with their parameters

\begin{tabular}{lcccccc}
\hline Element & Model & $\mathrm{C}_{0}$ & $\mathrm{C}_{1}$ & $\mathrm{C}_{0} /\left(\mathrm{C}_{0}+\mathrm{C}_{1}\right)$ & $\mathrm{a}(\mathrm{m})$ & $\mathrm{r}^{2}$ \\
\hline $\mathrm{Au}$ & Spherical & 1305.13 & 1026.75 & 55.97 & 271.9 & 0.996 \\
$\mathrm{As}$ & Spherical & 200000 & 200000 & 50.00 & 463.0 & 0.994 \\
$\mathrm{Sb}$ & Spherical & 6.83 & 5.49 & 55.44 & 515.4 & 0.996 \\
\hline
\end{tabular}


obtained with the $75^{\text {th }}$ percentile. Figure 4 shows the indicator semivariogram for $\mathrm{Au}\left(\mathrm{IAu}_{75}\right)$ using this cutoff. Semivariogram $\mathrm{IAu}_{75}$ was best fitted by a spherical model with a range of $362.6 \mathrm{~m}$ (Table 3). However the nugget effect of this indicator semivariogram (70.28\% of the sill value) was even higher than those of the semivariogram of the raw data sets $(55.97 \%$ of the sill value). Semivariogram $\mathrm{ISb}_{75}$ was also fitted by a spherical model and in this case the nugget effect was somewhat lower, $41.21 \%$ of the sill value.

Patterns of spatial variability revealed by the indicator semivariograms of the three studied elements were rather close to those of individual semivariograms obtained from the raw data sets. Thus, both individual and indicator semivariograms of $\mathrm{Au}, \mathrm{As}$ and $\mathrm{Sb}$ show
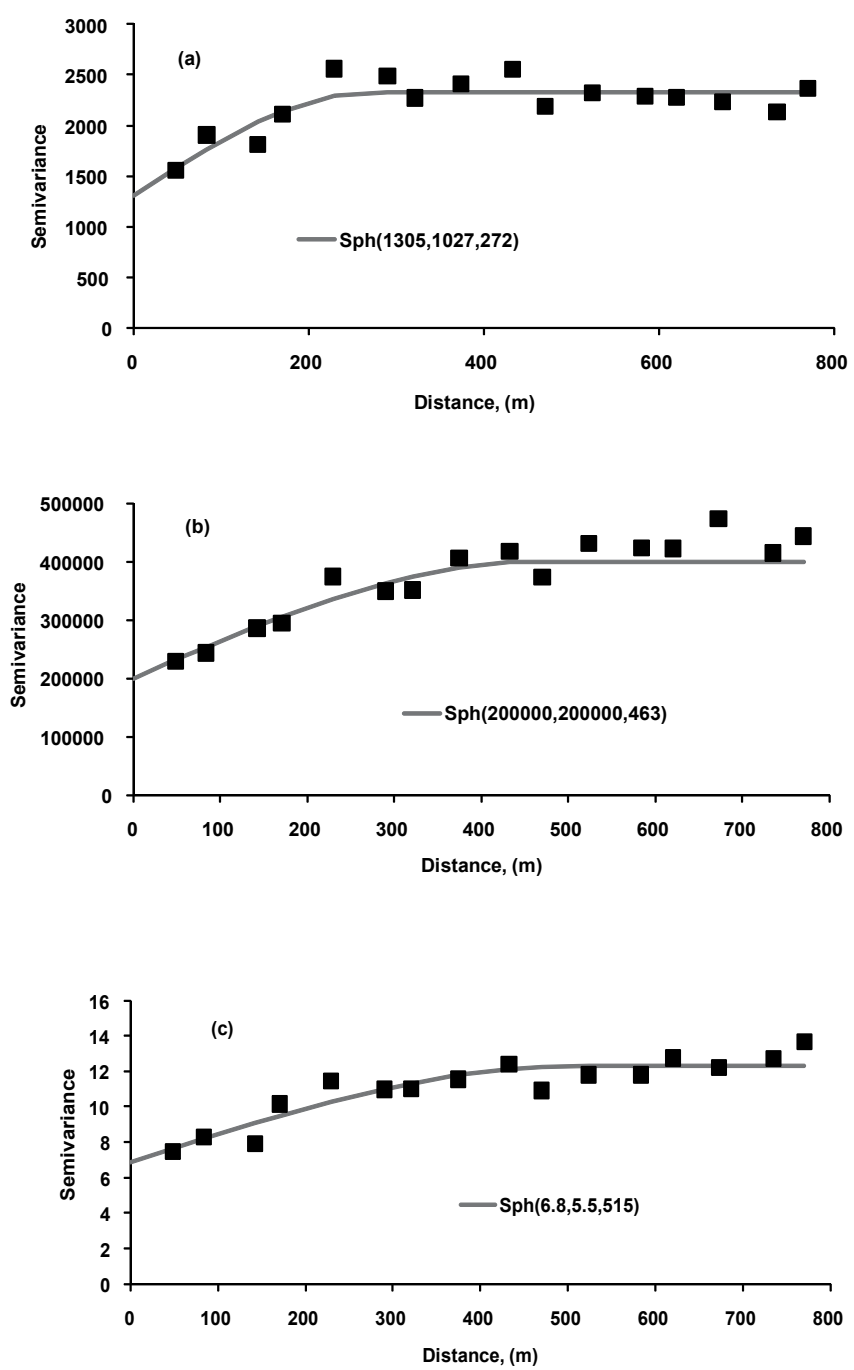

Figure 3. Experimental semivariograms and fitted models for $\mathrm{Au}(\mathrm{a}), \mathrm{As}(\mathrm{b})$ and $\mathrm{Sb}(\mathrm{c})$. that continuity patterns at small distances are not very different, suggesting a high spatial variation at small distances.

Common practice has shown that cross semivariograms present smaller nugget variance than individual direct semivariograms (VIEIRA et al., 1997; Paz GonZÁlez et al., 2001). In order to investigate if coregionalisation could improve the description of spatial continuity and reduce the estimation errors of the kriging variance, cross-semivariograms for Au versus As and $\mathrm{Au}$ versus $\mathrm{Sb}$ were constructed. Figure 4 shows these experimental cross semivariograms with corresponding fitted models and the respective parameters are listed in Table 4. The cross semivariogram Au x As was best fitted by a gaussian model with a dependence ratio of
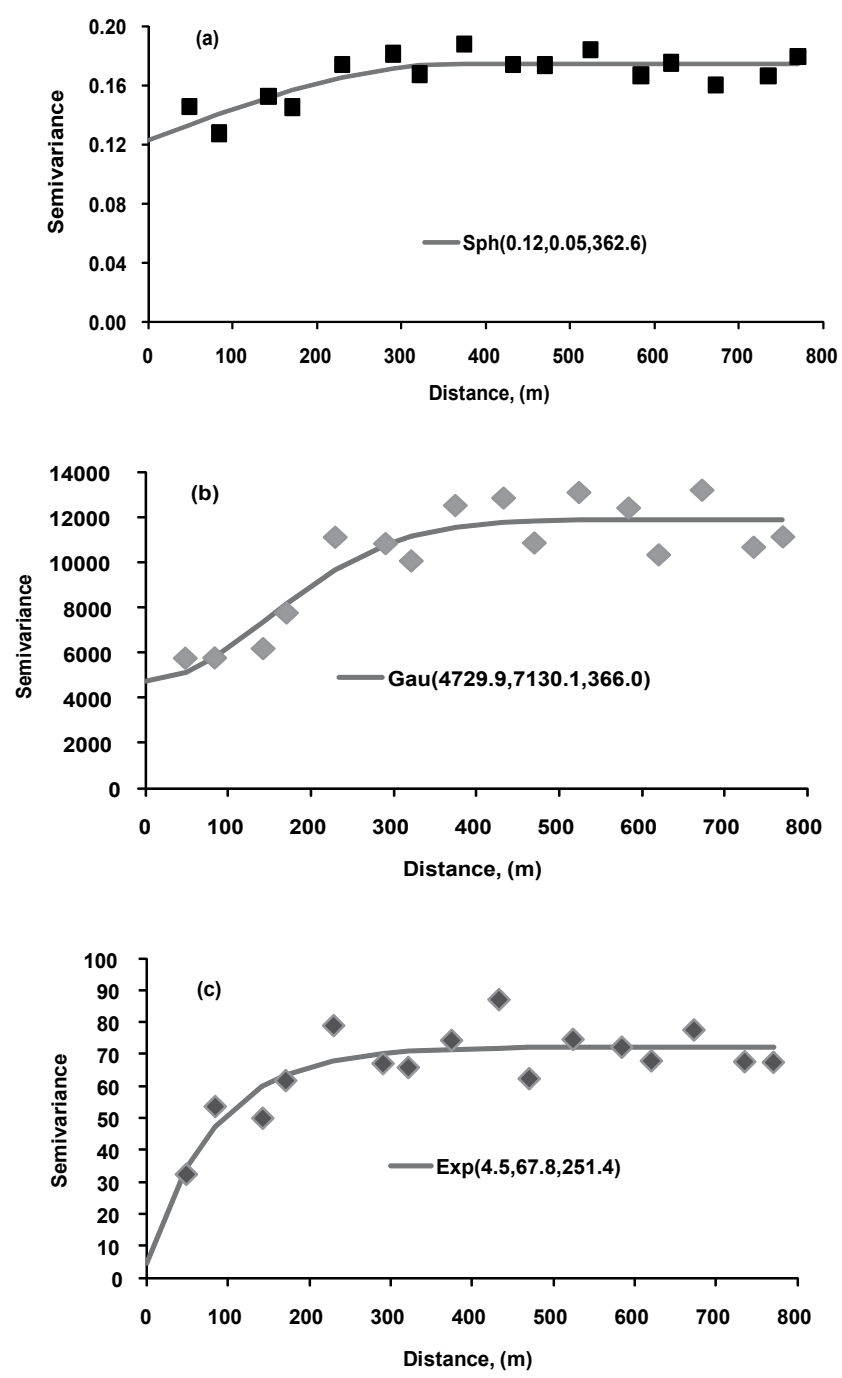

Figure 4. Experimental indicator semivariogram and fitted model for $\mathrm{Au}$ (a) and experimental cross semivariograms and fitted models for Au vs As (b) and Au vs Sb (c). 
Table 3. Fitted indicator semivariogram models with their parameters

\begin{tabular}{lcccccc}
\hline Variable & Model & $\mathrm{C}_{0}$ & $\mathrm{C}_{1}$ & $\mathrm{C}_{0} /\left(\mathrm{C}_{0}+\mathrm{C}_{1}\right)$ & $\mathrm{a}(\mathrm{m})$ & $\mathrm{r}^{2}$ \\
\hline I Au $75^{\text {th }}$ percentile & Spherical & 0.123 & 0.052 & 70.28 & 362.6 & 0.996 \\
$\mathrm{I} \mathrm{Sb} 75^{\text {th }}$ percentile & Spherical & 0.068 & 0.097 & 41.21 & 500.0 & 0.995 \\
\hline
\end{tabular}

Table 4. Fitted cross-semivariogram models with their parameters

\begin{tabular}{lcrrrrr}
\hline Variables & Model & \multicolumn{1}{c}{$\mathrm{C}_{0}$} & $\mathrm{C}_{1}$ & $\mathrm{C}_{0} /\left(\mathrm{C}_{0}+\mathrm{C}_{1}\right)$ & $\mathrm{a}(\mathrm{m})$ & $\mathrm{r}^{2}$ \\
\hline $\mathrm{Au}$ vs As & Gaussian & 4729.9 & 7130.1 & 39.88 & 366.0 & 0.836 \\
$\mathrm{Au}$ vs Sb & Exponential & 4.5 & 67.8 & 2.61 & 251.4 & 0.708 \\
\hline
\end{tabular}

$39.88 \%$ and a range of $366 \mathrm{~m}$. The cross semivariogram $\mathrm{Au} \times \mathrm{Sb}$ was best fitted by an exponential model with only $2.61 \%$ dependence ratio and a range of $251.3 \mathrm{~m}$. Thus, the reduction in the value of the nugget variance was higher in the case of $\mathrm{Au}$ versus $\mathrm{Sb}$ than in the case of $\mathrm{Au}$ versus As.

Therefore, cokriging clearly improved the spatial continuity at small distances. Because the nugget variances in the cross semivariograms were significantly reduced, mainly in the case of $\mathrm{Au} \times \mathrm{Sb}$, this nugget value perhaps better describes laboratory analytical errors rather than variability occurring within the shortest sampling interval (PAZ GonZÁlez et al., 2001). This is consistent with the fact that analytical values below detection limit are grouped at detection limit.

Once spatial continuity was modeled, ordinary kriging, indicator kriging and cokriging were performed to generate geochemical maps. Kriging maps for $\mathrm{Au}, \mathrm{As}$ and $\mathrm{Sb}$ are shown in figure 5. Gold distribution is characterized by two mineralization zones within the study area where maximum values occur. These zones are well delineated and they are located near the top and near the bottom of the contour map in figure 5. However, kriging contour maps also show that there is not a total correspondence between areas with maximum values of $\mathrm{Au}$, As and $\mathrm{Sb}$. Actually, the micro-region on the bottom of the Au kriging map (Figure 5) does not appear in the kriging maps for As and $\mathrm{Sb}$. The similitudes in the micro region with maximum values near the top of the map in $\mathrm{Au}$, As and $\mathrm{Sb}$, are more conspicuous. Thus the three kriging maps also show clear differences, suggesting variability in the mineralization processes of $\mathrm{Au}, \mathrm{As}$ and $\mathrm{Sb}$ at the study scale. Because processes inducing spatial variation during mineralization are superimposed, the individual effect of factors affecting the distribution of $\mathrm{Au}, \mathrm{As}$ and $\mathrm{Sb}$ is not always evident.

Indicator kriging also was used as an alternative in analyzing and interpreting geochemical data. Au map obtained by indicator kriging is shown in Figure 6 . Contour kriging maps clearly delineate the two zones with $\mathrm{Au}$ mineralization within the study area.

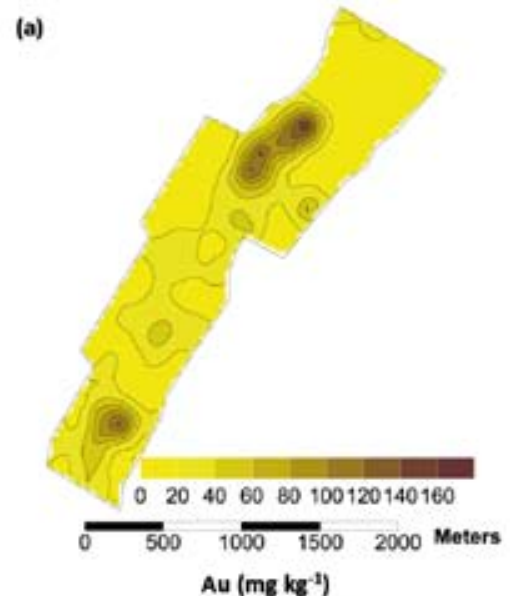

(b)
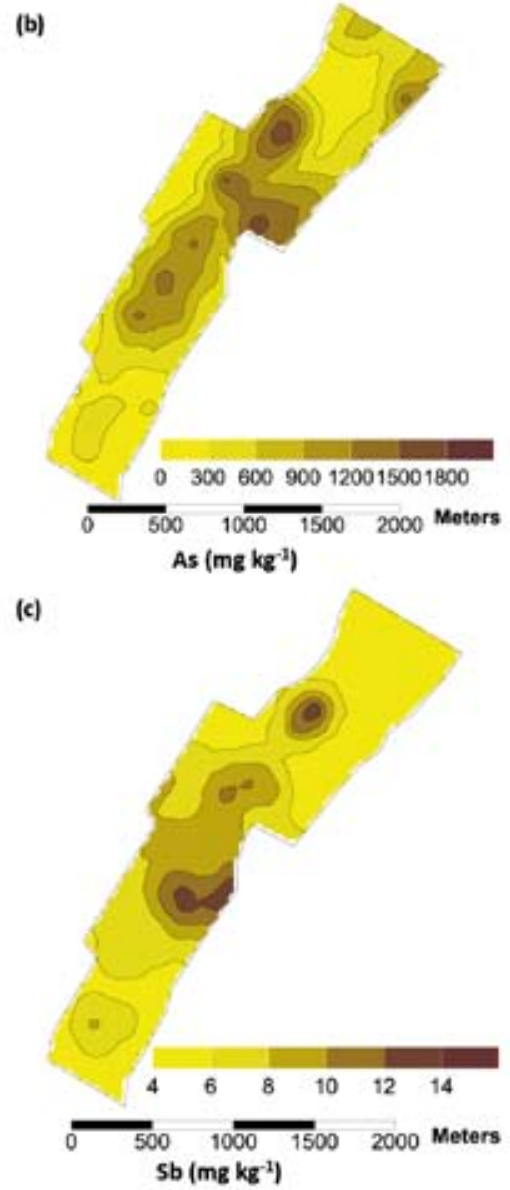

Figure 5. Kriging maps of $\mathrm{Au}(\mathrm{a})$, As (b) and $\mathrm{Sb}$ (c). 
Next, kriging and cokriging maps for $\mathrm{Au}$ are compared, in order to test the possible advantages in using coregionalization for estimation purposes. Figure 7 shows the maps of Au estimations obtained with cokriging using both $\mathrm{As}$ and $\mathrm{Sb}$ as the secondary variable. Basically, kriging (Figure 5) and cokiging maps (Figure 7) for Au present the same results, with a little more detail on the cokriged map, owing to the contribution of the variability of $\mathrm{As}$ or $\mathrm{Sb}$, and in spite

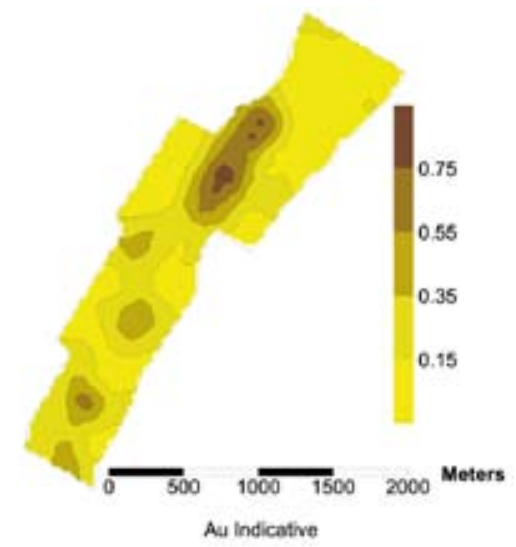

Figure 6. Indicator Kriging map of Au.
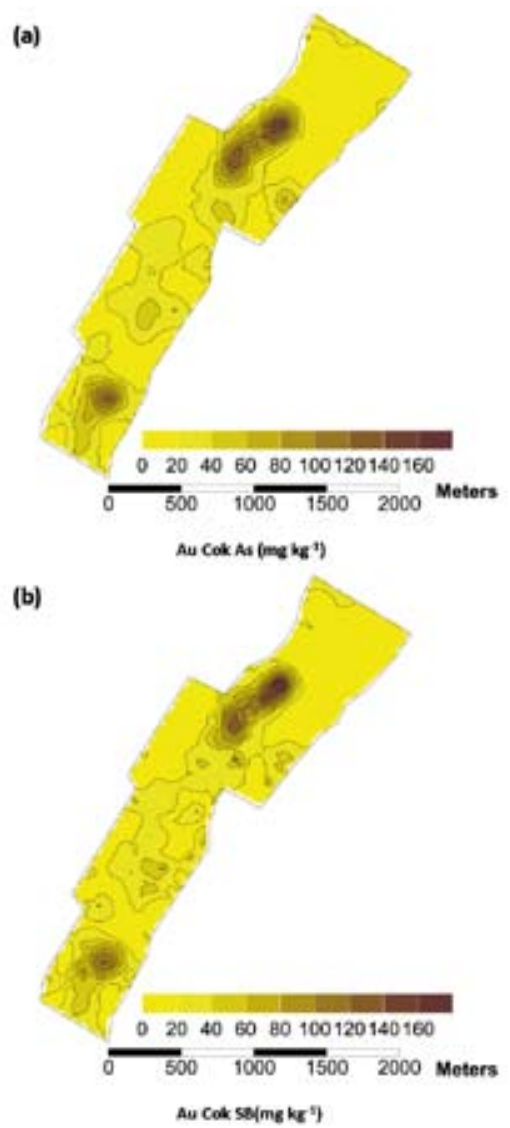

Figure 7. Cokriging maps of Au vs. As (a) and Au vs. Sb (b). of the low correlation coefficient of the concentration of $\mathrm{Au}$ with these two elements. Thus, cokriging and ordinary kriging estimations were somewhat alike. The limited improvement obtained by cokriging is related with the smaller nugget effect of crosssemivariograms when compared with individual semivariograms.

Semivariogram analysis and kriging maps illustrate possible environmental processes operating within the plot and allowed inferences to be made about factors controlling the spatial distribution of $\mathrm{Au}$, As and $\mathrm{Sb}$. Kriging maps provide additional evidence that different processes controls the contents of $\mathrm{Au}$, As and $\mathrm{Sb}$ within the study area. Therefore, the geostatistical approach has demonstrated to be a highly effective method to separate the studied plot into homogeneous small zones characterized by similitude and differences in the mineralization processes.

\section{CONCLUSIONS}

1. $\mathrm{Au}, \mathrm{As}$ and $\mathrm{Sb}$ are not normally distributed owing to their mineralization processes for high values and the analytical detection limit for low values.

2. Semivariogram, cross-semivariogram and indicator semivariogram analysis were equivalent for the spatial variability assessment all with high nugget effect values reflecting the nature of the spatial continuity.

3. Kriging, cokriging and indicator kriging were equivalent for mapping $\mathrm{Au}, \mathrm{As}$ and $\mathrm{Sb}$ variability and to identify micro regions with distinct values for all of the study variables. A combination of both ordinary and indicator kriging seem to be the ideal for delineating geochemical anomalies.

\section{REFERENCES}

CHILÉS, J.P.; DELFINER, P. Geostatistics. Modeling Spatial Uncertainty. Wiley Series in Probability and Statistics. John Wiley, 1999. 720p.

CAMBARDELLA, C.A.; MOORMAN, T.B.; NOVAK, J.M., PARKIN; T.B.; KARLEN, D.L.; TURCO, R.F.; KONOPKA, A.E. Field-scale variability of soil properties in central Iowa soils. Soil Science Society of America Journal, v.58, p. 15011511, 1994.

GOLDEN SOFTWARE. Surfer plotting software information brochure. Golden. CO. USA, 1999. 619p.

GOOVAERTS, P. Geostatistics for natural resources evaluation. Oxford: Oxford University Press, 1997. 483p. (Applied Geostatistics Series)

JIMÉNEZ ESPINOSA, R.; CHICA OLMO, M. Application of geostatistics to identify gold-rich areas in the Finisterre- 
Fervenza region, NW Spain. Applied Geochemistry v. 14, p.133-145, 1999.

JOURNEL, A.G. Nonparametric estimation of spatial distributions. Mathematical Geology. v.15, p.445-468, 1983.

JOURNEL, A.G.; HUIJBREGTS, J. Mining Geostatistics. London: Academic Press, New York, San Francisco, 1978. 600p.

LECOMTE, P.; SONDAG, F. Regional geochemical reconnaissance in the Belgian Ardennes, secondary dispersion patterns in stream sediments. Mineral Deposits, v.15, p. 47-60, 1980.

PAZ GONZÁLEZ, A.; TABOADA CASTRO, M.T.; VIEIRA, S.R. Geostatistical analysis of heavy metals in a one-hectare plot under natural vegetation in a serpentine area. Canadian Journal of Soil Science, v.81, p.469-479, 2001.

PORTER, D.; ÁLVAREZ MORÁN, B. Mineralizaciones de oro del Noroeste de España. In: GARCÍA GUÍNEA, J.; MARTÍNEZ FRÍAS, J. (Ed.). Recursos minerales de España, (Colección Textos Universitarios no. XV): CSIC Publication Services, 1992. p.849-860.

REIS, A.P.; SOUSA, A.J; CARDOSO FONSECA, E. Application of geostatistical methods in gold geochemical anomalies identification (Montemos-O-Novo, Portugal). Journal of Geochemical Exploration, v.77, p.45-63, 2003.

REIS, A.P.; SOUSA, A.J.; FERREIRA DA SILVA, E.; PATINHA, C.; FONSECA, E.C. Combining multiple correspondence analysis with factorial kriging analysis for geochemical mapping of the gold-silver deposit at Marrancos (Portugal). Applied Geochemistry, v.19, p.623-631, 2004.

SOUSA, A.J. Geostatistical data analysis-an application to ore body typology. In: Geostatistics, v. 2, p. 851-860, 1989.

Van MEIRVENNE, M., PANNIER, J., HOFMAN, G.; LOUWAGIE, G. Regional characterization of the long-term change in soil organic carbon under intensive agricultura. Soil Use and Management, v.12, p.86-94. 1996.

VIEIRA, S.R.; NIELSEN, D.R.; BIGGAR, J.W.; TILLOTSON, P.H. The scaling of semivariograms and the kriging estimation. Revista Brasileira de Ciência do Solo, v.21, p.523-533. 1997.

VIEIRA, S.R. Geoestatística em estudos de variabilidade espacial do solo. In: NOVAIS, R.F., ALVAREZ, V.H., SCHAEFER, G.R. (Ed.). Tópicos em Ciência do Solo. Viçosa: Sociedade Brasileira de Ciência do Solo, v.1, p.1-54, 2000. 
